\title{
MODEL OF THE STRUCTURE OF MOTOR VEHICLES FOR THE CRITERION OF THE TECHNICAL LEVEL ON ACCOUNT OF POLLUTANT EMISSION
}

\author{
MODEL STRUKTURY POJAZDÓW SAMOCHODOWYCH DLA KRYTERIUM \\ POZIOMU TECHNICZNEGO ZE WZGLĘDU NA EMISJĘ ZANIECZYSZCZEN゙*
}

\begin{abstract}
Inventory of total vehicle pollution emission is only possible through the use of emission modelling. One of the most difficult problems in modelling total emission from motor vehicles is the identification of the structure of vehicle fleet. While it is possible to use vehicle registration data to model the numerosity of elementary vehicle categories, it is very difficult to design representative driving cycles for vehicles in separate categories, in the absence of empirical evidence. The article proposes two models of the structure of motor vehicles for the criterion of technical level on account of pollutant emission. The method of modelling the intensity of use of motor vehicles by elementary categories on account of pollutant emission, outlined in this article, is the first unique undertaking in this field on a global scale. This method was used for inventorying pollutant emission from motor vehicles in Poland, in the years 2000-2015.
\end{abstract}

Keywords: motor vehicles, inventory of pollutant emission, motor vehicle categories.

\begin{abstract}
Inwentaryzacja całkowitej emisji zanieczyszczeń samochodowych jest możliwa tylko dzięki zastosowania modelowania emisji zanieczyszczeń. Jednym z najtrudniejszych problemów modelowania całkowitej emisji zanieczyszczeń z pojazdów samochodowych jest identyfikacja ich struktury. O ile jest możliwe wykorzystanie danych zwiazanych z rejestracja pojazdów samochodowych do modelowania liczności kategorii pojazdów samochodowych, o tyle wyznaczenie reprezentatywnych przebiegów pojazdów elementarnych kategorii jest zadaniem bardzo trudnym ze względu na brak wyników badań empirycznych. W artykule zaproponowano dwa modele struktury pojazdów samochodowych dla kryterium poziomu technicznego ze względu na emisję zanieczyszczeń. Przedstawiony w niniejszym artykule sposób modelowania intensywności użytkowania pojazdów samochodowych kategorii elementarnych ze względu na emisję zanieczyszczeń jest pierwszym unikatowym przedsięwzięciem w tym zakresie w skali światowej. Metodę tę zastosowano do inwentaryzacji zanieczyszczeń pojazdów samochodowych w Polsce w latach 2000-2015.
\end{abstract}

Slowa kluczowe: pojazdy samochodowe, inwentaryzacja emisji zanieczyszczeń, kategorie pojazdów samochodowych.

\section{Introduction}

The aim of this paper is to present the author's original mathematical model of intensity of using motor vehicles to be applied for inventorying emissions from road transport. The measure of car use intensity, in case of quantifying the release of pollutants within one year, is an annual vehicle mileage. Determining the intensity of motor vehicle use is one of the most difficult tasks in the inventory of pollutant emission from road transport.

Numerous publications, including both scientific papers $[6,7,18$, $24,25,27,31,35]$ and methodological manuals, as well as reports from pollutant emission inventories $[1,8,14-17,19-21,23,28,30$, 32], do not contain any models of intensity of using motor vehicles. In case of quantifying the emission of pollutants at local scale, as e.g. in urban areas, the results of empirical studies made with the use of sensors to identify traffic characteristics and vehicle type (among others: induction loops and camera systems) have often been used to estimate vehicle mileage $[24,25]$. In the latter case, the estimation of traffic intensity is only correct for vehicle categories at a very elevated level of aggregation, e.g. for such categories as small vehicles (passenger cars and light duty commercial vehicles) and large vehicles (heavy duty vehicles and buses). Consequently, the latter data is completely useless for application in the software commonly used for inventorying pollution from road transport, e.g. COPERT (Computer Programme for calculating Emissions from Road Traffic [14, 18]. The same is valid when traffic intensity data is applied in a local scale, using traffic simulators such as VISUM, VISSIM, TREM and VADIS [7]. Similarly, the use of complex systems, such as results of empirical research and vehicle traffic modelling, including neural networks [24] or Newell kinematic waveforms for vehicle traffic modelling [35], do not provide opportunities for identifying the intensity of car use, taking into account the different vehicle classification criteria, due to the requirements of software for emission estimation, e.g. COPERT.

Some publications, including, among others, reports from pollutant emission inventories [20, 28, 30,32], contain only qualitative descriptions of procedures for determining the annual mileage of cars, which are based on data recorded during technical inspection reviews. These data are used to establish the annual mileage of cumulative categories; these mileage are estimated as average values based on vehicle data. However, there are no generalizations, and even more so, attempts to model the intensity of use of motor vehicles. In these reports, there is only a qualitative assessment of motor vehicle use intensity indicating, namely, that newer cars have higher average annual mileage than older cars, and therefore vehicles with better environmental performance due to emissions are more heavily used [20,28].

(*) Tekst artykułu w polskiej wersji językowej dostępny w elektronicznym wydaniu kwartalnika na stronie www.ein.org.pl 
Account taken of the above-mentioned state of knowledge, it was deemed purposeful, for both cognitive and practical reasons, to attempt to generalize knowledge about how the intensity of motor vehicle use depends on vehicle quality due to pollutant emission. The practical aspect of modelling the intensity of use of motor vehicles, according to their environmental characteristics, is unequivocal: it is the only possibility to provide data for the inventory of traffic pollutant emissions in view of the lack of, at least in Poland, empirical data on annual mileage of cars of different ecological categories.

The model of intensity of motor vehicle use, developed by the authors, constitutes the first unique attempt on a global scale to solve the above important problem linked to the use of motor vehicles. The experience gained by both the authors [3-5] and the practitioners in the environmental impact assessment of road traffic, with the use of the developed model, make it possible to formulate positive opinions about its usefulness.

\section{Bases for modelling the total pollutant emission from motor vehicles}

The total pollutant emission from motor vehicles can only be determined through the use of emission modelling. [1, 3-8, 13-21, $23-25,27,28,30-32,35]$. The same is valid for the total energy consumption by motor vehicles [13]. In case of fuel consumption, however, it is possible to estimate, or at least approximate, this amount [11]. This is why, it is necessary to model pollutant emissions from road transport in order to assess the environmental pollution by motor vehicles.

The model of total pollutant emission is simple: the total pollutant emission constitutes a superposition of emission released from individual vehicles $[3,8,13-19,23]$. The above is underlain by the following assumptions $[3,8,13]$ :

- the intensity of the emission of particular pollutants is an additive,

- inventory of pollutants concerns substances in the state emitted from vehicles, not the substances that are subject to environmental changes.

The intensity of pollutant emissions associated with the use of motor vehicles with internal combustion engines is the sum of pollutant emissions for the states of $[3,8,13-19,23]$ :

- internal combustion engine heated to a stable temperature,

- internal combustion engine warm up,

- fuel evaporation from the car fuel system.

$$
E_{x}=E_{x s}+E_{x h}+E_{x V}
$$

where: $E_{x}-$ the intensity of emission of pollutant ,x”,

$\mathrm{E}_{\mathrm{xs}}$ - the intensity of pollutant emission intensity for internal combustion engine heated up to a stable temperature, $\mathrm{E}_{\mathrm{xh}}$ - the intensity of pollutant emission for the engine warm phase,

$\mathrm{E}_{\mathrm{xV}}$ - the intensity of pollutant emission for evaporation from the car fuel system.

Due to the purpose of the article, further considerations will be made using the example of emissions from diesel engines heated to a stable temperature. The modelling of the structure of vehicle fleet, which is the subject of this work, is also applicable to the remaining two states of the engine [3, 8, 13-19, 23].

The most significant challenge in modelling total emissions from motor vehicles is model identification. Of course, it is impossible to model pollutant emissions from all individual vehicles. First of all, the concept of vehicle categories is introduced in pollution modelling. Category means in philosophy the concept that introduces the structure, and therefore the term denotes a class of objects that have certain characteristics and interrelated relationships. The basic criteria for classifying motor vehicles into respective categories include [3, 8, 13-19, 23]:

- vehicle construction purpose,

- contractual size of vehicle or of internal combustion engine,

- properties resulting from the construction solutions applied,

- fuel type applied,

- technological level, with special regard to pollutant emission.

Taking into account the adopted criterial characteristics, vehicles displaying all the above characteristics qualify to the elementary category of motor vehicles. Whereas, the cumulated category of motor vehicles embraces vehicle types displaying various criterial characteristics. Consequently, there exist different levels of cumulation of motor vehicles within individual categories.

In modelling of pollutant emission, the notion of traffic conditions has been introduced, characterized by the properties of vehicle traffic. Consequently, it is assumed, that the intensity of pollutant emission constitutes a superposition of emissions from individual vehicles under particular traffic conditions which determine pollutant emission.

The conditions for motor vehicle traffic have been modelled, using software for emission inventory, as typical vehicle driving patterns in traffic situations [3, 8, 13-19, 23]:

- in cities - urban,

- outside cities - rural,

- on highways and expressways.

There is also a possibility to separate, from a model accounting for urban driving cycle, a segment pertaining to street congestion situations; in the latter circumstances, models accounting for urban driving cycles have been replaced by models of motor vehicle motion mode [9]:

- in the street congestion situations,

- in cities, disregarding the street congestion situations.

In modelling pollutant emission from motor vehicles, under model traffic conditions, a more specific dependence of pollutant emission on the velocity process is additionally considered [1, 3, 8, 13-19, 21, 23]. Most often, the average value of velocity is assumed as the zerodimensional characteristics of the velocity process $[1,3,8,13-19,21$, 23]. The specific distance emission - a derivative of pollutant emission (mass) with respect to the distance travelled by a vehicle - is utilized in modelling of the total emission of pollutants [3, 13].

Account taken of the assumptions adopted, the intensity of the total pollutant emission, averaged over one year, may be modelled for separate elementary categories, under each of the modelled traffic conditions, as the value proportionate to [1, 3, 8, 13-19, 23]:

- the number of vehicles in a category,

- the distance travelled by a vehicle, representative of a given category, over one year, what constitutes a measure of the vehicle use intensity,

- the characteristics of pollutants specific distance emission for a vehicle representative of a category.

$$
E_{a x}=N \cdot p \cdot b_{x}
$$

where: $\mathrm{N}-$ the number of vehicles in a given category,

$\mathrm{p}$ - the distance travelled by vehicle representative of a given category over one year,

$\mathrm{b}_{\mathrm{x}}$ - the specific distance emission of pollutant , $\mathrm{x}$ ”.

The intensity of the total emission from motor vehicles is a superposition of emissions from individual vehicle categories, under considered particular traffic conditions, which determine pollutant emissions $[3,13]$. 
The intensity of the total annual emission of pollutants with respect to averaging over one year is called annual emission [3-5, 13], while in national reports on yearly emission inventories, the term: "national annual emission of pollutants' is applied [3-5].

1, 23]:

The criteria for classifying motor vehicles include $[1,3,8,13-19$,

1. Vehicle purpose:

- passenger cars,

- light commercial vehicles (vans),

- heavy duty trucks,

- urban buses,

- coaches,

- motorcycles,

$\circ$ mopeds ${ }^{1}$.

2. Contractual size, properties and technical level of motor vehicles:

- the contractual size is considered with respect to: (i) volume of engine displacement: for passenger cars and light duty vehicles as well as for motorcycles and mopeds, and (ii) maximum vehicle mass - for heavy duty trucks and buses,

- the type of combustion system of internal combustion engine: spark ignition engines and compression ignition engines,

- the type of cycle: four stroke and two stroke engines,

- the technological level of road vehicles with regard to both: the stage of environmental protection regulations concerning effects of motor vehicle operation modes and to the date when the vehicle was first placed on the market,

- the fuel type applied: motor gasoline, diesel, LPG - Liquefied Petroleum Gas, natural gas (CNG - Compressed Natural Gas and LNG - Liquefied Natural Gas) as well as other nonconventional fuels.

The number of vehicles in the individual elementary categories can be, at least approximately, determined based on the information on registered cars. One of the most significant challenges in identification of models accounting for the total emission from motor vehicles is the assessment of the intensity of use of motor vehicles belonging to individual categories, and particularly to elementary categories. In the framework of developing software to assist with the calculation of road transport emission, by the end of the $20^{\text {th }}$ century, there were undertaken research programmes in the developed countries, aiming at the estimation of annual distances travelled by motor vehicles from elementary categories $[8,15,19]$. Despite that large financing was dedicated to these programmes, only a part of their results found reasonable practical application, among others in Germany and Switzerland $[8,15,19]$. The analysis of results of study on the structure of vehicle fleet in Western Europe, on the basis of reports of the programme CORINAIR (Core Inventory of Air Emissions) [15, 19], made it possible to produce a model of the delay of the condition of motorization in Poland, in relation to the state of motorization in Western Europe [12]. This model, however, can only be used for categories at the highest cumulation level, e.g. passenger cars, light duty vehicles, heavy duty vehicles and buses, as well as motorcycles and mopeds.

The subject of modelling the intensity of use of vehicles by elementary categories was undertaken in view of the lack of sufficient empirical material to determine the annual mileage of vehicles representing elementary categories and, in particular, in view of the technical level of cars in Poland.

\footnotetext{
1 In accordance with the Law of 20 June 1997: Act on Road Traffic (Official Journal of 2012, item 1137), motor vehicle means any vehicle that is motor powered, except mopeds and rail cars. Irrespective of the above definition, modelling emission from road transport also covers mopeds as elements of the set of motor vehicles.
}

\section{Modelling the intensity of use of motor vehicles by elementary categories}

Information pertaining to car registration may provide grounds to develop the description of the vehicle fleet structure. This concerns the purpose of vehicles and their contractual size. In particular, the environmental performance of a motor vehicle is determined by the date of placing the car on the market [2-5]. Of course, there are some difficulties in taking efficient advantage of data from bases on car registration, to the description of the structure of vehicle fleet, since the criteria for vehicle classification are sometimes very demanding with respect to details, as is the case with the COPERT software programme.

Despite these difficulties, the past experience of authors suggests the possibility of effective use of official data on the number of vehicles, contained in the databases of the Central Information System of Vehicles and Drivers (CEPiK) for use in the COPERT software programme [2-5].

The significant challenge in describing the structure of vehicle fleet constitute data on the annual mileage of vehicle, representative of individual elementary categories. Up to now, there are no information systems for collecting data on annual mileage travelled by particular vehicles, despite that such attempts have been undertaken. However, if such an undertaking is successful, then there will be no data on vehicle mileage $\mathrm{s}$ in previous years, and the analysis of emission trends of individual pollutants plays an important role in the inventory of pollutant emission from motor vehicles $[4,5]$.

The up-to-date surveys of annual car mileage $s$ in Poland carried out on sets of vehicles with statistical inertia make it possible, however, to approximate the annual mileage of cumulative vehicle categories, describing the intended use of vehicles and, to a lesser extent, their contractual size and constructional characteristics [11]. The major challenge is the determination of annual mileage for elementary categories of vehicles due to pollutant emission. Consequently, it was undertaken to model the intensity of use of motor vehicles for elementary categories of vehicles due to release of pollutants.

From the information contained in the databases used in the software build for determining vehicle emission characteristics, primarily from the INFRAS AG software [21], results a characteristic feature for the annual mileage of elementary vehicles of different emission classes.

These categories are described by the names of successive stages of motor vehicle homologation regulations with respect to the emission of pollutants $[2,33,34]$ :

- for cars with a maximum mass lower than $3.5 \mathrm{Mg}$ for Euro $1-4$ rules, and a reference weight of less than 2.61 Mg for Euro 5 and 6: Pre Euro (or Conventional), Euro 1, Euro 2, Euro 3, Euro 4, Euro 5 and Euro 6,

- for cars with a maximum mass of more than $3.5 \mathrm{Mg}$ for Euro $\mathrm{I}-\mathrm{IV}$, and with a reference mass greater than $2.61 \mathrm{Mg}$ for Euro V and VI: Pre Euro (or Conventional), Euro I, Euro II, Euro III, Euro IV, Euro V and Euro VI.

Sometimes these categories are even more detailed, depending on sub-steps of further Euro regulations, e.g. Pre Euro (ECE 15/00-01, ECE 15/02, ECE 15/03 and ECE 15/04), Euro 5 and Euro 6 (Euro 6 and Euro $6 \mathrm{c}$ ).

The characteristic feature of the annual mileage of elementary category vehicles of different emission classes is the fact, that newer vehicles have recently been in use, which have a higher class with respect to environmental performance. This fact is also confirmed by the results of review studies conducted in connection with balancing of fuel consumption [8, 20, 21, 28, 30, 32].

The model of the intensity of using motor vehicles, for elementary categories of vehicles with respect to pollutant emission, was decided 
to be adopted in the form of a growing function of the values describing successive stages of vehicle approval regulations due to emission of pollutants - these values are growing as more and more recent phases of regulations appear. The proposed model is constructed according to the criterion of functional similarity (behavioral model) $[10,26]$.

The modeling of the intensity of use of vehicles by elementary environmental performance categories with respect to pollutant emission, consists of the following elements:

1. Arbitrary allocation of non-negative real numbers to individual environmental performance categories, according to the principle that higher quality environmental categories correspond to higher numbers. The way of assigning numbers to individual environmental performance categories of vehicles used in this work is presented in tables 1-4.

Table 1. The way of assigning numbers to individual environmental performance categories of passenger cars

\begin{tabular}{||c|c|}
\hline Category & $y$ \\
\hline Pre ECE & 0 \\
\hline ECE $15 / 00-01$ & 1 \\
\hline ECE $15 / 02$ & 2 \\
\hline ECE $15 / 03$ & 3 \\
\hline ECE $15 / 04$ & 4 \\
\hline Euro 1 & 5 \\
\hline Euro 2 & 6 \\
\hline Euro 3 & 7 \\
\hline Euro 4 & 8 \\
\hline Euro 5 & 9 \\
\hline Euro 6 & 10 \\
\hline
\end{tabular}

Table 2. The way of assigning numbers to individual environmental performance categories of light duty vehicles

\begin{tabular}{|c|c|}
\hline Category & $\mathrm{y}$ \\
\hline Coventional & 0 \\
\hline Euro 1 & 1 \\
\hline Euro 2 & 2 \\
\hline Euro 3 & 3 \\
\hline Euro 4 & 4 \\
\hline Euro 5 & 5 \\
\hline Euro 6 & 6 \\
\hline
\end{tabular}

Table 3. The way of assigning numbers to individual environmental performance categories of heavy duty vehicles, urban buses and long range coaches

\begin{tabular}{|c|c|}
\hline Category & $\mathrm{y}$ \\
\hline Conventional & 0 \\
\hline Euro I & 1 \\
\hline Euro II & 2 \\
\hline Euro III & 3 \\
\hline Euro IV & 4 \\
\hline Euro V & 5 \\
\hline Euro VI & 6 \\
\hline
\end{tabular}

Table 4. The way of assigning numbers to individual environmental performance categories of motorcycles and mopeds

\begin{tabular}{|c|c|}
\hline Category & $\mathrm{y}$ \\
\hline Coventional & 0 \\
\hline Euro 1 & 1 \\
\hline Euro 2 & 2 \\
\hline Euro 3 & 3 \\
\hline
\end{tabular}

2. Adoption of models describing the relative intensity $-\mathrm{k}-$ of using of motor vehicles belonging to elementary environmental performance categories with respect to pollutant emission, in the form:

Model 1 is in the form [29]:

$$
k_{1}=1-\exp \left(-a \cdot x^{c+1}\right)\left(1-k_{\min }\right)
$$

Model 2 was adopted as a function:

$$
k_{2}=\left\{\frac{\operatorname{arctg}[d \cdot(x-0.5)]}{\operatorname{arctg}(0.5 \cdot d)-\operatorname{arctg}(-0.5 \cdot d)}+0.5 \cdot \frac{1+k_{\min }}{1-k_{\min }}\right\} \cdot\left(1-k_{\min }\right)(4)
$$

whereat:

$$
x=\frac{y}{y_{\max }} .
$$

where: $\quad y_{\max }-$ the maximum value of numbers ' $y$ ' from tables 1-4 for a given year of estimating pollutant emission.

The value $\mathrm{k}_{\min }$ is the relative intensity of using motor vehicles belonging to the lowest category of environmental performance. The model parameters are:

- for model 1: a, c;

- for model 2: d.

3. Scaling of the average annual mileage of motor vehicles belonging to elementary environmental performance categories, with respect to pollutant emission to the average annual mileage of motor vehicles of cumulative categories.

In figure 1 , a comparison is presented of both models for $\mathrm{k}_{\min }=$ 0.25 as well as model parameters: $\mathrm{a}=6.908, \mathrm{c}=2.5$ and $\mathrm{d}=7$.

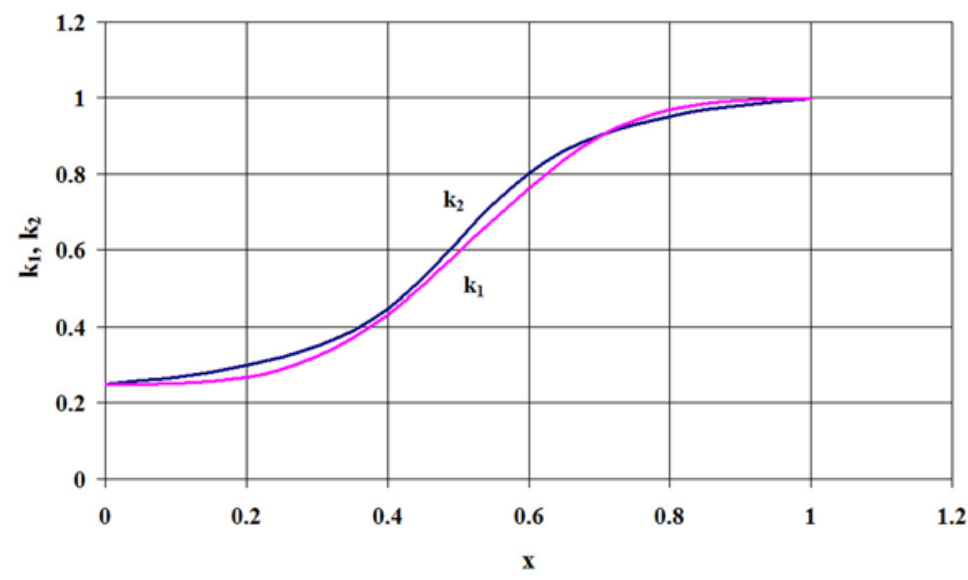

Fig. 1. Models of relative intensity of use of motor vehicles belonging to elementary environmental performance categories with respect to pollutant emission 


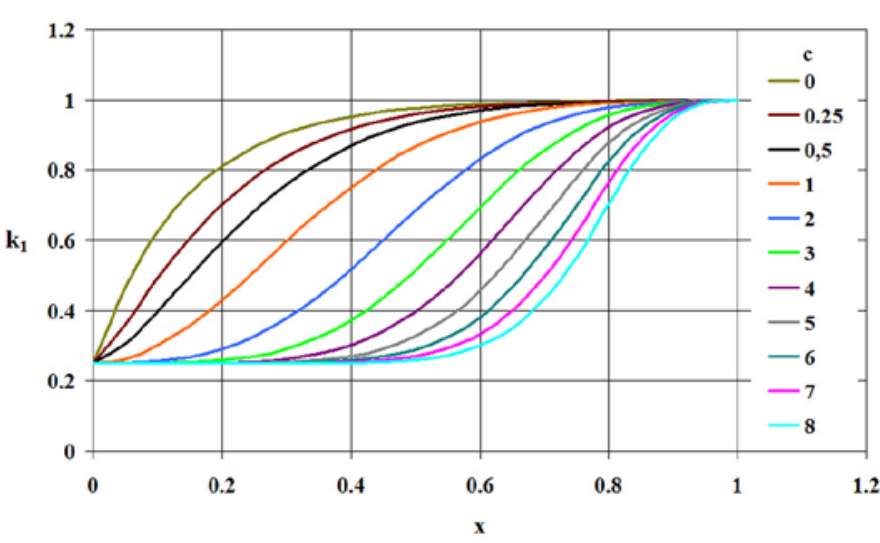

Fig. 2. Results of testing model 1 due to variable parameter ' $c$ '

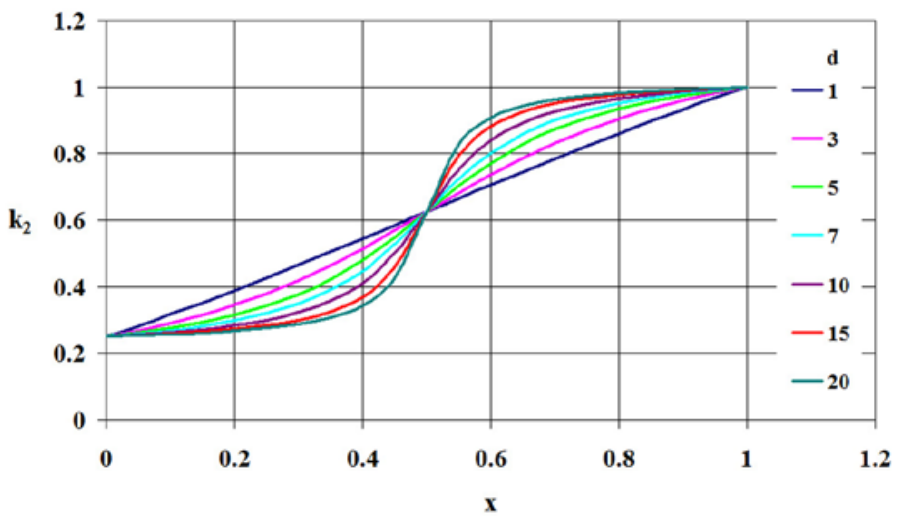

Fig. 3. Results of testing model 2 due to variable parameter ' $d$ '

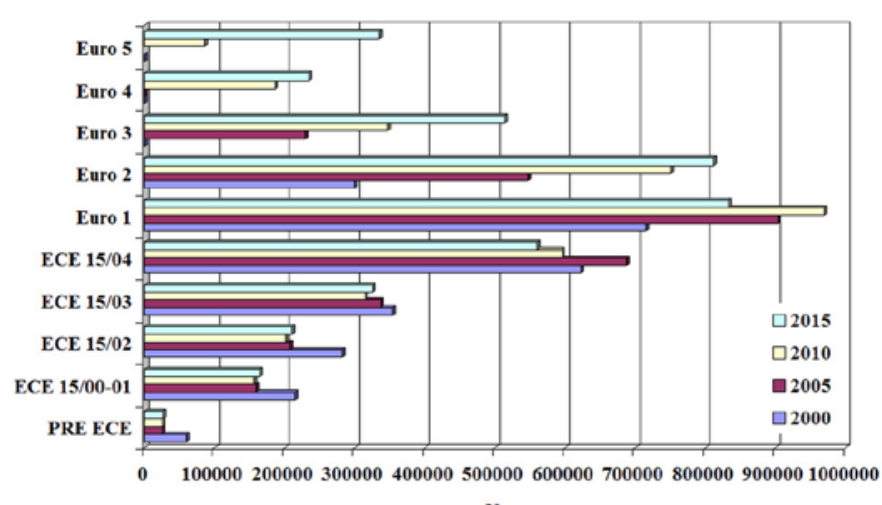

Fig. 4. Number of passenger cars with spark ignition engines and displacement volume contained with the limits $(1.4 \div 2) \mathrm{dm}^{3}$, by environmental performance categories

The models were tested for their parameters. The test results are given in figures 2 and 3.

Model 1 is much more sensitive to parameter 'c'. Regardless of the parameter, antisymmetry is significant for model 2 . The existing knowledge, based on the authors' own research and on data from INFRAS AG software as well as from the EU Member State reports under the CORINAIR program, indicates that model 1 is more effective in modeling the intensity of use of motor vehicles due to their category of emission characteristics.

Of course, due to the lack of sufficiently rich empirical evidence, the major challenge is to identify the model. However, this difficulty

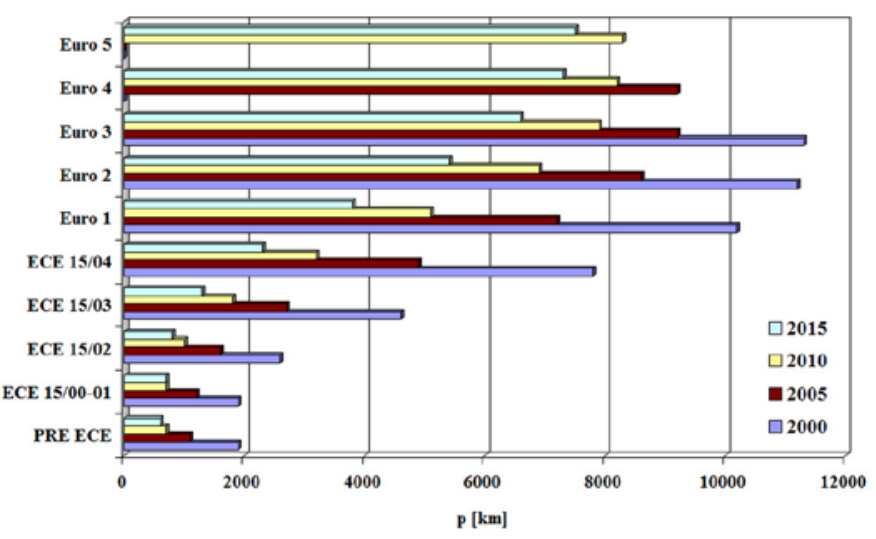

Fig. 5. Average annual mileage of passenger cars with spark ignition engines and displacement volume contained with the limits $(1.4 \div 2) \mathrm{dm}^{3}$, by environmental performance categories

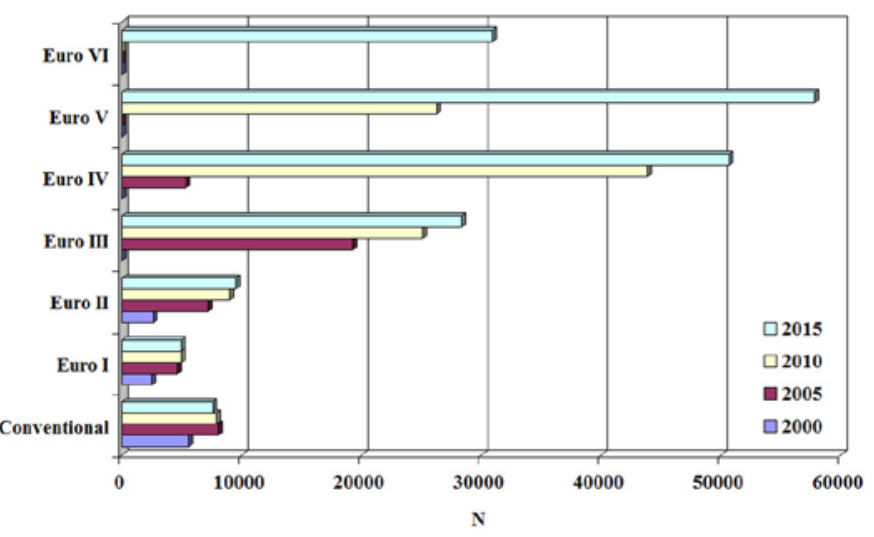

Fig. 6. Number of heavy duty trucks with the maximum mass contained in the limits $(34 \div 40) \mathrm{Mg}$, by environmental performance categories.

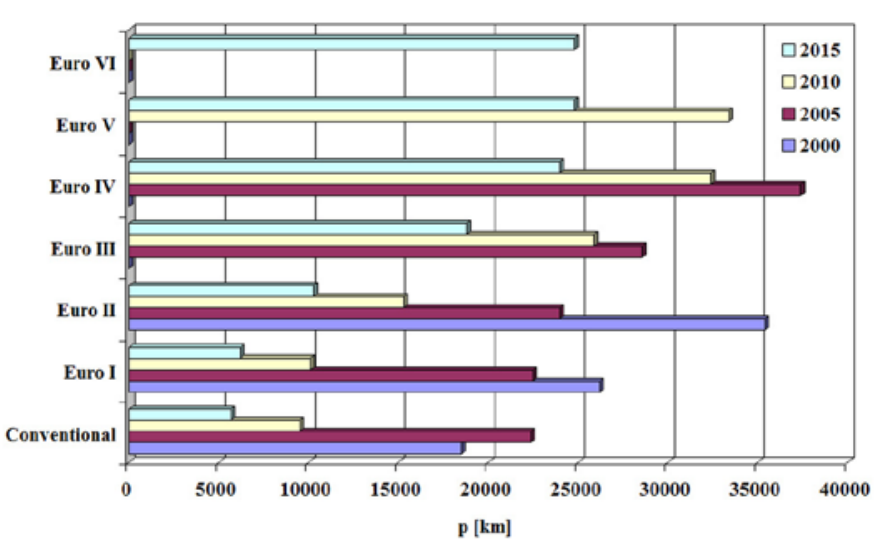

Fig. 7. Average annual mileage of heavy duty trucks with the maximum mass contained in the limits $(34 \div 40) \mathrm{Mg}$, by environmental categories.

is greatly mitigated by the fact, that the scope of the model parameters under consideration can be limited, based on the existing knowledge, to the limits:

- for model 1: $\quad c=1 \div 4$

- for model 2: $\mathrm{d}=7 \div 15$;

while the sensitivity of the models within the scope of the above values of both parameters is not strong.

It is impossible, in practice, to apply the classic methods of identification [22] of the proposed models. Therefore, the models are tuned, while their verification is performed through the test of compliance of 


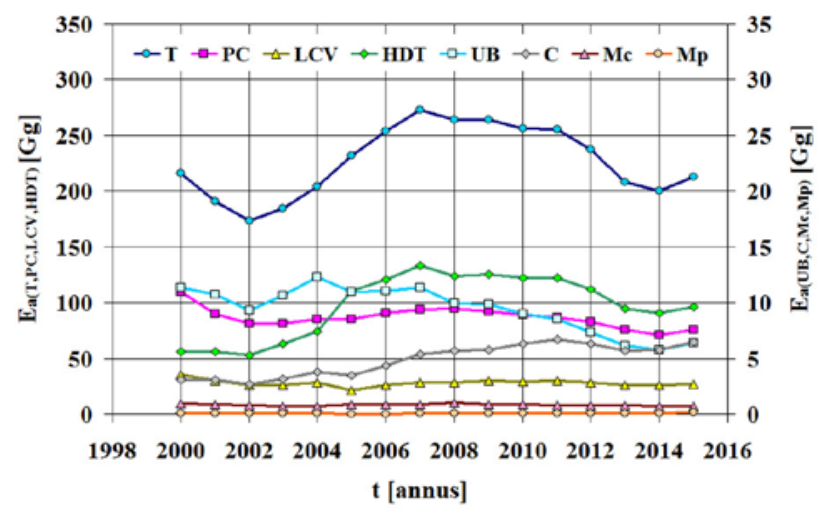

Fig. 8. National annual emission of nitrogen oxides from vehicles of cumulated categories.

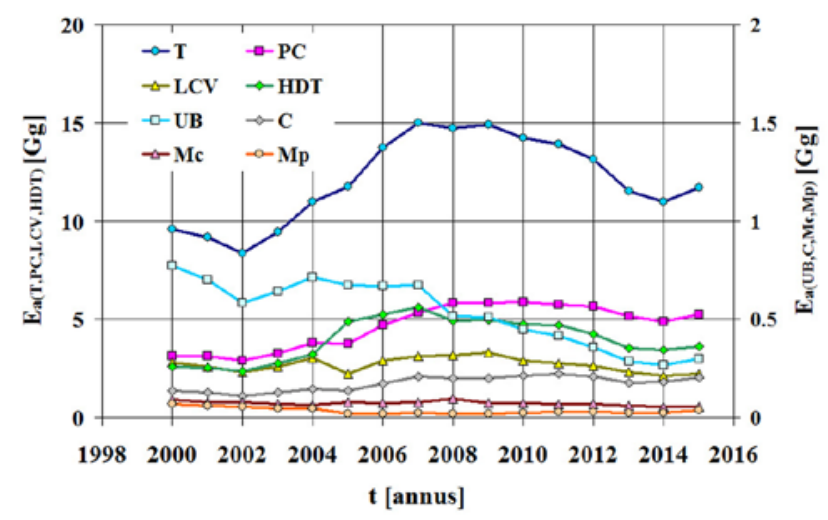

Fig. 9. National annual emission of particulates PM10 from vehicles of cumulated categories.

the total annual fuel consumption by motor vehicles obtained via the modelling with the official data of the Central Statistical Office [3-5].

Figures 4-7 illustrate, for example, the number and annual mileage of vehicles of the two cumulative categories: passenger cars with spark ignition engines and displacement volume contained with the limits $(1.4 \div 2) \mathrm{dm}^{3}$ as well as heavy duty trucks with the maximum mass within the limits $(34 \div 40) \mathrm{Mg}$, for the years 2000, 2005, 2010 and 2015. The number of vehicles by environmental performance categories for the years 2000, 2005 and 2010 was determined on the basis of the data contained in CEPiK, while for the year 2015 - the car's numerical structure was estimated based on the data of the Central Statistical Office (due to lack of data from CEPiK). The Model 1 intensity of use of vehicles with the parameters $\mathrm{a}=6.908$ and $\mathrm{m}=2.5$ was used to determine vehicle mileage by respective environmental performance categories.

The results of the use of the model clearly show: increasing annual mileage of vehicles of higher environmental performance categories.

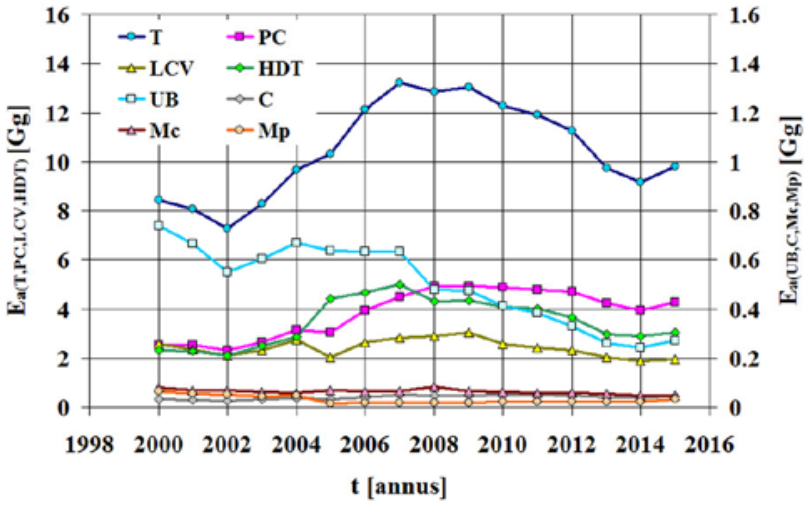

Fig. 10. National annual emission of particulates PM2.5 from vehicles of cumulated categories.

The use of the model 1, accounting for the intensity of using motor vehicles has made it possible to investigate the annual national pollutant emission from motor vehicles in Poland [3-5].

Figures 8-10 show the sample results for the years 2000-2015national annual emission $-E_{a}$ oxides of nitrogen, particulates PM10 and particulates PM2.5 for cumulative categories: all motor vehicles - T, passenger cars - PC, light commercial vehicles - LCV, heavy duty trucks - HDT, urban buses - UB, coaches $-\mathrm{C}$, motorcycles $-\mathrm{Mc}$ and mopeds $-\mathrm{Mp}$.

It is clear from figures $8-10$ that, for example, the national annual emission of substances which constitute one of the most serious problems in the use of motor vehicles, have been decreasing since around 2007, despite the fact, that the number of vehicles and the intensity of their use have been considerably increasing. This is the result of technical progress in the design of motor vehicles.

\section{Recapitulation}

The way of modelling the intensity of use of motor vehicles belonging to elementary categories with respect to pollutant emission, outlined in this article, is the first unique undertaking in this field on a global scale. The proposed models are built according to the criterion of functional similarity. Tests on the models show that their sensitivity within the scope of real values of model parameters is not too large, to unable the models to be fine tuned with the use, as the compliance criterion, of the total fuel consumption data from models and those officially published. The presented results of applying one of the developed models are consistent with the state of the art. An example of practical use of one of the developed models is the inventory of pollutant emission from motor vehicles in Poland in the years 2000-2015, made using the COPERT software. These results have been presented in the official reports of the European Union.

\section{References}

1. 2006 IPCC Guidelines for National Greenhouse Gas Inventories. http://www.ipcc-nggip.iges.or.jp/public/2006gl/ vol2.html. (2016-12-06).

2. AVL Emission Testing Handbook 2016.

3. Bebkiewicz K, Chłopek Z, Szczepański K, Zimakowska-Laskowska M. Issues of modeling the total pollutant emission from vehicles. Proceedings of the Institute of Vehicles. 2017; 110 (1): 103-118.

4. Bebkiewicz K, Chłopek Z, Szczepański K, Zimakowska-Laskowska M. Results of air emission inventory from road transport in Poland in 2014. Proceedings of the Institute of Vehicles 2017; 110 (1): 77-88.

5. Bebkiewicz K, Chłopek Z, Szczepański K, Zimakowska-Laskowska M. The influence of the properties of vehicles traffic on the total pollutant emission. Proceedings of the Institute of Vehicles 2017; 110 (1): 89-102.

6. Borge $\mathrm{R}$ et al. Development of road traffic emission inventories for urban air quality modeling in Madrid (Spain). 21st USEPA International Emission Inventory Conference. April 13-16, 2015. San Diego (California). 
7. Borrego $\mathrm{C}$ et al. Integrated modelling of road traffic emissions: application to Lisbon air quality management. Cybernetics and Systems. An International Journal 2004; 35(5-6): 535-548.

8. BUWAL (Bundesamt für Umwelt, Wald und Landschaft), INFRAS AG (Infrastruktur-, Umwelt- und Wirtschaftsberatung). Luftschadstoffemissionen des Strassenverkehrs 1950-2010, BUWAL-Bericht 1995; 255.

9. Chłopek Z, Biedrzycki J, Lasocki J, Wójcik, P. Comparative examination of pollutant emission from an automotive internal combustion engine with the use of vehicle driving tests. Combustion Engines 2016; 164 (1): 56-64.

10. Chłopek Z, Piaseczny L. Remarks about the modelling in science researches. Eksploatacja i Niezawodnosc - Maintenance and Reliability 2001; 11 (4): 47-57.

11. Chłopek Z, Waśkiewicz J. Projections of the fuel consumption by the road transport in Poland. Journal of KONES 2013 ; 20 (2): 33-39.

12. Chłopek Z. Testings of vehicle ecological structure in European Union countries in consideration of emission model adaptation into polish conditions. Journal of KONES 2000: 65-76.

13. Chłopek Z. Zasady modelowania zużycia paliwa i energii oraz emisji zanieczyszczeń związanych z użytkowaniem pojazdów drogowych. (Principles of modeling of fuel and energy consumption and emission of pollutants associated with the use of road vehicles). Technika Transportu Szynowego 2015; 12: 262-267. (In Polish).

14. COPERT Training 5. COPERT 5 vs COPERT 4. European Environment Agency. 2016. http://emisia.com/sites/default/ files/COPERT 5 features.pdf. (2016-12-06).

15. CORINAIR - Coordinated Information on the Environment in the European Community - Air. http://reports.eea.europa.eu/ EMEPCORINAIR4/en/page002. html. (2016-12-06).

16. COST 319. Estimation of pollutant emissions from transport. http://lat.eng.auth.gr/ COPERT/. (2016-12-06).

17. EMEP/EEA air pollutant emission inventory guidebook - 2016. European Environment Agency. http://www.eea. europa.eu/publications/ emep-eea-guidebook-2016. (2016-12-06).

18. Gkatzoflias D, Kouridis Ch, Ntziachristos L, Samaras Z. COPERT 4 Computer programme to calculate emissons from road transport User manual (version 9.0). European Environment Agency. Emisia SA. 2012. (2016-12-06).

19. http://www.eea.europa.eu/publications/EMEPCORINAIR5. (2014-08-24).

20. Informative inventory report Sweden 2016. Swedish Environmental Protection Agency. Stockholm. 2016.

21. INFRAS AG. Handbook emission factors for road transport 3.2. Quick reference. Version 3.2. Bern, 2014.

22. Mańczak K.: Metody identyfikacji wielowymiarowych obiektów sterowania. Warszawa: Wydawnictwa Naukowo-Techniczne, 1979. (In Polish).

23. MEET. Methodologies for Estimating Air Pollutant Emissions from Transport. http://lat.eng.auth.gr/COPERT/. (2016-12-06).

24. Naranjo J E, Jimenez F, Serradilla F J, Zato J G. Floating car data augmentation based on infrastructure sensors and neural networks. IEEE (Institute of Electrical and Electronics Engineers) Transactions on Intelligent Transportation Systems 2012; 13: 107-114, https://doi. org/10.1109/TITS.2011.2180377.

25. Reynolds A W, Broderick B M. Development of an emissions inventory model for mobile sources. Transportation Research Part D: Transport and Environment 2016; 5: 77-101, https://doi.org/10.1016/S1361-9209(99)00025-5.

26. Rosenbluth A., Wiener N: The role of models in science. Phil. Sci. 1945: 12 (4), https://doi.org/10.1086/286874.

27. Saikawa et al. The impact of China's vehicle emissions on regional air quality in 2000 and 2020: a scenario analysis. Atmospheric Chemistry and Physics 2011; 11: 9465-9484, https://doi.org/10.5194/acp-11-9465-2011.

28. Sandmo T. The Norwegian Emission Inventory 2013. Documentation of methodologies for estimating emissions of greenhouse gases and long-range transboundary air pollutants. Statistics Norway. Oslo-Kongsvinger. 2013.

29. Vibe I I. Nowoje o rabocziem cikle dvigatieliej (Вибе И.И.: Новое о рабочем цикле двигателей - New about working cicle of engines). Sverdlovsk (Свердловск): Mashgiz Moskow (Машгиз Москва), 1962. (In Russian).

30. Wakeling D et al. UK informative inventory report (1990 to 2015). Final Version (v1.0). Ricardo Energy \& Environment. March 2017. https://uk-air.defra.gov.uk/assets/documents/reports/cat07/1703161205_GB_IIR_2017_Final_v1.0.pdf.

31. Wang H Z, Ni D H, Chen C Y, Li J. Stochastic modeling of the equilibrium speed-density relationship. Journal of Advanced Transportation 2013; 1(47): 126-150, https://doi.org/10.1002/atr.172.

32. Winther M.: Danish emission inventories for road transport and other mobile sources. Inventories until the year 2010. National Environmental Research Institute. University of Aarhus. 2012. Scientific Report No. 24. http://www.dmu.dk/Pub/SR24.pdf.

33. Worldwide emission standards. Heavy duty \& off-road vehicles. Delphi. Innovation for the real world. 2015/2016.

34. Worldwide emission standards. Passenger cars and light duty vehicles. Delphi. Innovation for the real world. 2016/2017.

35. Zhou $\mathrm{X}$ et al. Integrating a simplified emission estimation model and mesoscopic dynamic traffic simulator to efficiently evaluate emission impacts of traffic management strategies. Transportation Research Part D: Transport and Environment 2015; 37: 123-136, https:/doi. org/10.1016/j.trd.2015.04.013.

\section{Zdzisław CHŁOPEK Katarzyna BEBKIEWICZ}

Institute of Environmental Protection - National Research Institute in Warsaw The National Centre for Emissions Management (KOBiZE)

ul. Chmielna 132/134, 00-805 Warsaw, Poland

E-mails: zdzislaw.chlopek@kobize.pl, katarzyna.bebkiewicz@kobize.pl 